\title{
Analysis of Inflation Trends and Measure to Contain Them
}

\author{
R. Ramamoorthy, Venkatraman, K. Poovarasan
}

\begin{abstract}
Swelling is a significant macroeconomic pointer, which estimates the adjustment in the general degree of costs of merchandise and ventures. The month to month time arrangement of the yearly expansion rate is characterized as the development pace of the month to month time arrangement of the shopper value list as for the comparing month of the earlier year. The yearly expansion rate may not generally be the fitting proportion of swelling, for the most part because of the way that it doesn't give cutting-edge data on the degree of swelling. The symphonious investigation demonstrates that the yearly expansion rate misshapes and defers the data regarding the month to month swelling rate. This end can be critical in the anticipating of the swelling rate, just as during the time spent financial basic leadership. The new strategy for the development of the yearly swelling rate estimates is proposed. The preferred position is that it can catch breaks and different hazards later on advancement of the time arrangement
\end{abstract}

Keywords: Inflation, Macroeconomic Indicator, Harmonic Analysis

\section{INTRODUCTION}

In standard financial matters, "swelling" alludes to a general ascent in costs estimated against a standard degree of obtaining power. Swelling is estimated by looking at two arrangements of products at two points in time, and figuring the expansion in expense not reflected by an increment in quality[1],[3],[5]. From 2003-07, the Indian economy has entered a high-development stage, averaging 8.6 percent per annum. . The extension in non-sustenance credit at 29.8 percent in the period 2003-07 is uncommon throughout the entire existence of the Indian economy.

Expansion implies a considerable and increment in the value level over some undefined time frame. The conduct of general cost is estimated through value list. Generally the entire deal value record is utilized to gauge expansion. Customer value record or cost of leaving file can be embraced in estimating the pace of swelling[2],[4],[6].

\section{A. Need For the Study}

The need of this examination is to quantify the adjustments in value level in Indian economy[7],[9],[11]. To investigation the costs which affecting the swelling and gauge the progressions affecting GDP, GNP and PIN.

\section{B. Scope of the Study}

- The present research study has an exceptionally wide extension. It covers different perspective which is having the effect on expansion.

- It demonstrates the different reasons of changes in Indian swelling rate[8],[10],[12].

- It thinks about the present patterns in swelling

\section{Limitations}

Data has just gathered from authority site and different productions

- Research is completely founded on optional information

- Knowledge of the scientist

- Time is one of the standard constraints in this exploration procedure

- Due to absence of programming, the whole databases are planned physically

\section{RESEARCH DESIGN}

The Research Design is an end-all strategy determining the technique and method for gathering and breaking down the model data[13], [15],[17] .

In this task the scientist utilized expressive investigation for gathering and breaking down data. Engaging examination studies are those investigations that arrangement the qualities of past data's[20],[22],[24]

\section{Trend Analysis \\ II.Percentage Analysis \\ III. Graphical}

Table 1 - Calculation Of Trend Value Of Last 7 Year Inflation Rate
Revised Manuscript Received on July 22, 2019.

Mr. R. Ramamoorthy Department of MBA, Bharath Institute of Higher Education and Research, Chennai, India.

Email: ramamoorthy0071@gmail.com

K. Venkatraman, Department of Civil Engineering, Bharath Institute of Higher Education and Research, Chennai, India.

Email: venkatraman.civil@bharathuniv.ac.in

K. Poovarasan, Department of MBA, Bharath Institute of Higher

Education and Research, Chennai, India.

Email: poovarasan7465@gmail.com 
Analysis of Inflation Trends and Measure to Contain Them

\begin{tabular}{|l|l|l|l|l|}
\hline YEAR & $\begin{array}{l}\text { INFLATION RATE } \\
\text { IN } \%(\mathrm{Y})\end{array}$ & $\mathrm{X}$ & $\mathrm{X}^{2}$ & $\mathrm{XY}$ \\
\hline 1998 & 5.9 & -3 & 9 & -17.7 \\
\hline 1999 & 3.3 & -2 & 4 & -6.6 \\
\hline 2000 & 7.2 & -1 & 1 & -7.2 \\
\hline 2001 & 4.7 & 0 & 0 & 0 \\
\hline 2002 & 4.0 & 1 & 1 & 4.0 \\
\hline 2003 & 5.0 & 2 & 4 & 10.0 \\
\hline 2004 & 5.8 & 3 & 9 & 17.4 \\
\hline TOTAL & 35.9 & & 28 & -0.1 \\
\hline
\end{tabular}

The equation of the straight line of the best fit

$$
Y=a+b x
$$

By the method of least squares, the value of $a$ and $b$ are

$$
\begin{aligned}
\mathrm{a} & =\sum \mathrm{Y} / \mathrm{N} \\
& =35.9 / 7 \\
& =5.12
\end{aligned}
$$

$$
\begin{aligned}
& \text { And } b=\sum X Y / \sum \mathrm{X}^{2} \\
& =-0.1 / 28 \\
& =-0.003
\end{aligned}
$$

Now the equation is

$$
\mathrm{Y}=5.12+(-0.003) \mathrm{X}
$$

Table 2 - Trend Values

\begin{tabular}{|l|l|l|}
\hline YEAR & $\mathrm{X}$ & \multicolumn{1}{|c|}{$\begin{array}{l}\text { TREND VALUES } \\
\text { Y=5.12+(-0.003)X }\end{array}$} \\
\hline 1998 & -3 & 5.129 \\
\hline 1999 & -2 & 5.126 \\
\hline 2000 & -1 & 5.123 \\
\hline 2001 & 0 & 5.120 \\
\hline 2002 & 1 & 5.117 \\
\hline 2003 & 2 & 5.114 \\
\hline 2004 & 3 & 5.111 \\
\hline
\end{tabular}

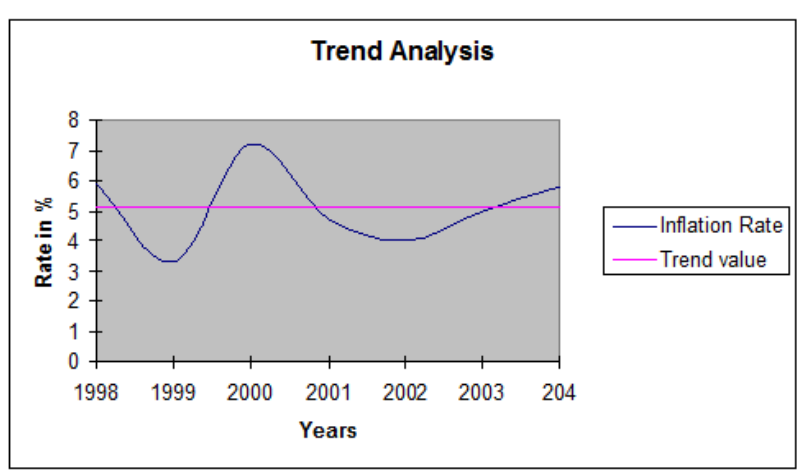

Figure 2 - Trend Values

Table 3 - Monthly Average Rate Of Inflation (1999-2004) Based On Wpi

\begin{tabular}{|l|l|}
\hline MONTH & WPI \\
\hline APR-99 & 4.3 \\
\hline MAY-99 & 3.8 \\
\hline JUN-99 & 3.1 \\
\hline JUL-99 & 2.3 \\
\hline AUG-99 & 2.2 \\
\hline SEPT-99 & 2.7 \\
\hline OCT-99 & 2.9 \\
\hline NOV-99 & 3.1 \\
\hline DEC-99 & 2.8 \\
\hline JAN-00 & 3.5 \\
\hline FEB-00 & 3.5 \\
\hline MAR-00 & 5.5 \\
\hline APR-00 & 6.5 \\
\hline MAY-00 & 6.4 \\
\hline JUN-00 & 6.5 \\
\hline JUL-00 & 6.5 \\
\hline AUG-00 & 6.1 \\
\hline SEPT-00 & 6.5 \\
\hline OCT-00 & 7.3 \\
\hline NOV-00 & 7.6 \\
\hline DEC-00 & 7.9 \\
\hline JAN-01 & 8.2 \\
\hline FEB-01 & 8 \\
\hline MAR-01 & 6.5 \\
\hline APR-01 & 6.5 \\
\hline MAY-01 & 6.3 \\
\hline JNN-01 & 6.6 \\
\hline & \\
\hline
\end{tabular}

\begin{tabular}{|l|l|}
\hline$\pi I-01$ & 6.5 \\
\hline AUG-01 & 6.1 \\
\hline SEPT-01 & 6.5 \\
\hline OCT-01 & 7.3 \\
\hline NOV-01 & 7.6 \\
\hline DEC-01 & 8.5 \\
\hline JAN-02 & 8.7 \\
\hline FEB-02 & 8.3 \\
\hline MAR-02 & 6.4 \\
\hline APR-02 & 5.4 \\
\hline MAY-02 & 5.6 \\
\hline JUN-02 & 5.3 \\
\hline JL-02 & 5.2 \\
\hline AUG-02 & 5.4 \\
\hline SEPT-02 & 5.8 \\
\hline OCT-02 & 6.5 \\
\hline NOV-02 & 7.2 \\
\hline
\end{tabular}




\begin{tabular}{|l|l|} 
DEC-02 & 8.3 \\
\hline JAN-03 & 8.5 \\
\hline FEB-03 & 7.8 \\
\hline MAR-03 & 5.4 \\
\hline APR-03 & 4.4 \\
\hline MAY-03 & 4.6 \\
\hline JNN-03 & 6.2 \\
\hline JUL-03 & 6.1 \\
\hline
\end{tabular}

\begin{tabular}{|l|l|}
\hline AUG-03 & 5.8 \\
\hline SEPT-03 & 6.3 \\
\hline OCT-03 & 7.2 \\
\hline NOV-03 & 6.2 \\
\hline DEC-03 & 5.6 \\
\hline JAN-04 & 6.3 \\
\hline FEB-04 & 5.8 \\
\hline MAR-04 & 5.2 \\
\hline
\end{tabular}

Interpretation:

During the period of 1999-2000 we can see in the first half of the year the Inflation rate comes down from $4.2 \%$ to $2.2 \%$. In this period there is a high export of IT related services but after September the trend shows that continuous increase in inflation rate from $2.2 \%$ to $5.6 \%$ because of poor monsoon, slow industrial growth \& change in International scenario, such as prices of the crude oil goes high[14],[16], [18].

One of the major factors for increasing inflation rate in 1999-00 was Nuclear Test.

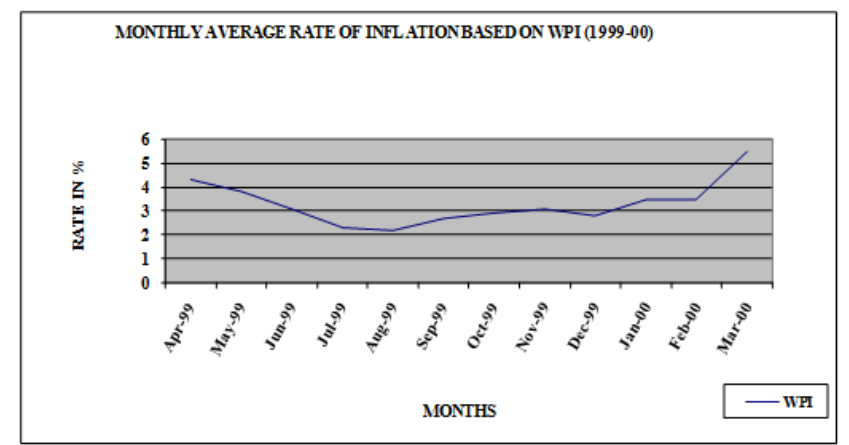

Figure 3 - Monthly Average Rate Of Inflation (1999-2004) Based On Wpi

Table 4 - Monthly Average Rate Of Inflation (2000-01 Based On Wpi

\begin{tabular}{|l|l|}
\hline MONTH & WPI \\
\hline APR-00 & 6.5 \\
\hline MAY-00 & 6.4 \\
\hline JUN-00 & 6.5 \\
\hline JUL-00 & 6.5 \\
\hline AUG-00 & 6.1 \\
\hline SEPT-00 & 6.5 \\
\hline OCT-00 & 7.3 \\
\hline NOV-00 & 7.6 \\
\hline DEC-00 & 7.9 \\
\hline JAN-01 & 8.2 \\
\hline FEB-01 & 8 \\
\hline MAR-01 & 6.5 \\
\hline
\end{tabular}

\section{RESULTS AND DISCUSSION}

- $\quad$ From the examination work it is discovered the rainstorm is having the effect in Indian swelling

- From the examination it is discovered that change in the pace of unrefined petroleum and oil based good influence the swelling[19],[21],[23]

- It is discovered that that during the economy year 2000-2001 resistance consumption increments 30\%, it influence the swelling

- Natural fiasco like Orissa twister, Gujrat seismic tremor having the terrible effect over the Indian Economy

\section{CONCLUSION}

This Research depends on swelling rate in India. Expansion is a financial disease in economy[25],[27],[29]. There are Three main consideration which is fluctuating swelling rate that is oil based good, unrefined petroleum and storm. The swelling make an awful effect over the Indian economy. The fares and imports have likewise make a terrible effect over the Indian Inflation rate. Information accumulation is done through different authority sites and distributions to get the learning about the expansion of India[31],[33].

\section{REFERENCES}

1) BharthVajan R., Ramachandran S.,Psychographic dimensions of training,2016,International Journal of Pharmacy and Technology,V-8,I-4,P-23727-23729

2) Balakrishnan P., Bharthvajan R.,A study on human resource planning in hospitals in Chennai City,2014,International Journal of Applied Engineering Research,V-9,I-22,P-7503-7507

3) Priyadarsini P., Bharthvajan R.,Role of emotional intelligence training programme in reducing the stress of the nurses,2014,International Journal of Applied Engineering Research,V-9,I-22,P-7411-7421

4) Kerinab Beenu G., Bharthvajan R.,Empirical analysis on the cosmetic buying behavior of young women in South India,2014,International Journal of Applied Engineering Research,V-9,I-22,P-7361-7366

5) Balakrishnan P., Bharthvajan R.,Whistling in the
wind,2014,International Journal of 
Applied Engineering Research,V-9,I-22,P-7586-7593

6) Krishnan B., Peter M.,Health hazards of Indian Bpo employee-an alarming issue,2014,International Journal of Applied Engineering Research,V-9,I-22,P-7336-7341

7) Kerinab Beenu G.H., Peter M.,Role of insurance in economic development,2014,International Journal of Applied Engineering Research,V-9,I-22,P-7532-7539

8) Balakrishnan P., Peter M., Priyadarsini P.,Efficiency of safety measures for wellbeing of employees in manufacturing industry,2014,International Journal of Applied Engineering Research,V-9,I-22,P-7376-7382

9) Anbarasi M., Praveen Kumar S.,Online sales promotions of herbal products and its effectiveness towards tanisha.com,2019,Indian Journal of Public Health Research and Development,V-10,I-1,P-195-200

10) Anbarasi M., Praveen Kumar S.,Various online marketing and promotions strategies to improve the validation towards the organic products in the pharmaceutical sectors,2019,Indian Journal of Public Health Research and Development,V-10,I-1,P-263-269

11) Loganathan R., Praveen Kumar S.,Grievance handling a key factor for solving issues of employees in an organization,2014,International Journal of Applied Engineering Research,V-9,I-22,P-7483-7491

12) Loganathan R., Praveen Kumar S.,Study on preference of private label brands in super and Hypermarkets,2014,International Journal of Applied Engineering Research,V-9,I-22,P-7327-7335

13) Smitha M., Praveen Kumar S.,Understanding stress and its managementamong the nurses in Chennai city,2014,International Journal of Applied Engineering Research,V-9,I-22,P-7560-7565

14) Kerinab Beenu G.H., Praveen Kumar S.,A study on the investment behavior of Chennai investors in mutual fund schemes,2014,International Journal of Applied Engineering Research,V-9,I-22,P-7520-7525

15) Loganathan R., Praveen Kumar S.,Retention strategies key for organizational productivity,2014,International Journal of Applied Engineering Research,V-9,I-22,P-7443-7447

16) Pavithra J., Ganesan M., Brindha G.,State wise analysis of microfinance sector in India,2016,International Journal of Pharmacy and Technology,V-8,I-4,P-23417-23432

17) Pavithra J., Ganesan M.,A comparative study on microfinance in India and abroad,2016,International Journal of Applied Business and Economic Research,V-14,I-8,P-5471-5476

18) Pavithra J., Ganesan M.,A study on awareness and impact of micro-financial schemes,2016,International Journal of Applied Business and Economic Research,V-14,I-8,P-5449-5460

19) Senthilmurugan P., Pavithra J.,Consumer preference towards organised retailing with reference to Big Bazaar,2014,International Journal of Applied Engineering Research,V-9,I-22,P-7469-7475

20) Senthilmurugan P., Pavithra J.,Implication of social media marketing in growing healthcare industry,2014,International Journal of Applied Engineering Research,V-9,I-22,P-7448-7456

21) Loganathan R., Pavithra J.,Consumer perception towards private label brand over other brands in super markets and hypermarkets,2014,International Journal of Applied Engineering Research,V-9,I-22,P-7355-7360

22) Kerinab Beenu G., Pavithra J.,Tradeâ€"off between liquidity and profitability in logistics industry,2014,International Journal of Applied Engineering Research,V-9,I-22,P-7398-7401

23) Kerinab Beenu G., Pavithra J.,A study on the prospective consumerâ€ $€^{\mathrm{TM}_{S}}$ perception towards utility cars in Chennai city,2014,International Journal of Applied Engineering Research,V-9,I-22,P-7526-7531

24) Pavithra J., Dilli Babu P., Ambuli T.V.,A study on budgetary control at Maruti Service Masters, Chennai,2014,International Journal of Applied Business and Economic Research,V-12,I-2,P-151-161

25) Pavithra J., Dilli Babu P., Ambuli T.V.,A study on customer satisfaction of retro Garments Pvt Ltd, Chennai,2014,International Journal of Applied Business and Economic Research,V-12,I-2,P-381-391

26) Kerinab Beenu G.H., Pavithra J., Senthilmurugan P.,A study on the influence of promotional activities for TATA ARIA among consumers in Chennai,2014,International Journal of Applied Engineering Research,V-9,I-22,P-7572-7578

27) Vijayaragavan S.P.,An investigative expert that's general FBG sensors,International Journal of Mechanical Engineering and Technology,V-8,I-8,PP-1500-1505,Y-2017

28) Vijayaragavan S.P.,Equalization routing protocol for Wi-Fi sensor strategy,International Journal of Mechanical Engineering and Technology,V-8,I-8,PP-1662-1666,Y-2017

29) Karthik B., Kiran Kumar T.V.U., Vijayaragavan P., Bharath Kumaran E.,Design of a digital PLL using 0.35 $\hat{\mathrm{I}}^{1}$ /4m CMOS technology,Middle East Journal of Scientific Research,V-18,I-12,PP-1803-1806,Y-2013

30) Kanniga E., Selvaramarathnam K., Sundararajan M.,Kandigital bike operating system,Middle - East Journal of Scientific Research,V
31) Jasmin M., Vigneshwaran T., Beulah Hemalatha S.,Design of power aware on chip embedded memory based FSM encoding in FPGA,International Journal of Applied Engineering Research,V-10,I-2,PP-4487-4496,Y-2015

32) Jasmin M.,Optimization techniques for low power VLSI circuits,Middle East Journal of Scientific Research,V-20,I-9,PP-1082-1087,Y-2014

33) Jasmin M., Vigneswaran T.,Fuzzy controller for error control of on - Chip communication,2017 International Conference on Algorithms, Methodology, Models and Applications in Emerging Technologies, ICAMMAET 2017,V-2017-January,I-,PP-1-5,Y-2017

\section{AUTHORS PROFILE}

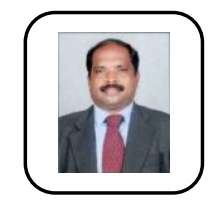

Mr. R. Ramamoorthy Assistant Professor, Department of MBA, Bharath Institute of Higher Education and Research, Chennai, India.

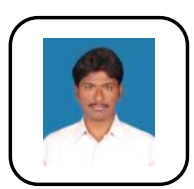

K. Venkatraman Assistant Professor, Department of Civil Engineering, Bharath Institute of Higher Education and Research, Chennai, India.

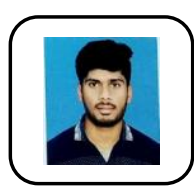

K. Poovarasan Student, Department of MBA, Bharath Institute of Higher Education and Research, Chennai, India. 